\title{
Drug use and associated demographic factors of freshman students in a Chilean University*
}

\author{
Uso de drogas e fatores demográficos associados entre estudantes no primeiro ano de uma \\ Universidade Chilena
}

\author{
Consumo de drogas y factores demográficos asociados en estudiantes de primer año de una \\ universidad Chilena
}

\section{Fredy Seguel P. ${ }^{1}$, Gama Santander M. ${ }^{2}$, María Lina Ramos S. ${ }^{3}$}

\begin{abstract}
Objective: to characterize the student population first enters the Universidad Austral de Chile in terms of drug use and associated factors. Methods: association study of drug use and demographic variables of 845 students. The self-administered questionnaire contained two main instruments, the detection pattern of alcohol and other drugs (DEP-ADO) and the AUDIT. Partnerships were established using parametricand nonparametric tests. Results: increased consumption of alcohol and marijuana was associated with male gender. The onset of drug and alcohol consumption did not differ significantly according to sex. The frequency of alcohol consumption on faculties has significant differences in men and women. The variables "where you live" and "who lives" was significantly related to consumption of amphetamine and marijuana. Conclusion: the main problem of this population is the consumption of alcohol, snuff and Marijuana.
\end{abstract}

Keywords: Students; Universities; Drug users; Street drugs; Age of onset

\section{RESUMO}

Objetivo: Caracterizar a população estudantil que ingressa pela primeira vez na Universidad Austral de Chile, em termos do uso de drogas e fatores demográficos associados. Métodos: Estudo de corte transversal e de associação do uso de drogas e variáveis demográficas de 845 alunos. O questionário autoadministrado continha dois instrumentos principais, o padrão de detecção de álcool e outras drogas. Foram estabelecidas associações por meio de testes paramétricos e não paramétricos. Resultados: O aumento do consumo de álcool e de maconha foi associado ao gênero masculino. O início do consumo de drogas e álcool não diferiu significativamente em função do gênero. A frequência de consumo de álcool teve diferenças significativas por faculdade entre homens e mulheres. As variáveis "lugar onde vive" e "com quem vive", foram significativamente relacionadas com o consumo de anfetaminas e maconha. Conclusão: O consumo de tabaco, álcool e maconha foi o principal identificado nessa população.

Descritores: Estudantes; Universidades; Usuários de drogas; Drogas ilícitas; Idade de início

\section{RESUMEN}

Objetivo: Caracterizar la población estudiantil que ingresa por primera vez en la Universidad Austral de Chile, en términos del uso de drogas y factores demográficos asociados. Métodos: Estudio de corte transversal y de asociación del uso de drogas y variables demográficas de 845 alumnos. El cuestionario autoadministrado contenía dos instrumentos principales, el patrón de detección de alcohol y otras drogas. Se establecieron asociaciones por medio de tests paramétricos y no paramétricos. Resultados: El aumento del consumo de alcohol y de marihuana fue asociado al género masculino. El inicio del consumo de drogas y alcohol no difirió significativamente en función del género. La frecuencia de consumo de alcohol tuvo diferencias significativas por facultad entre hombres y mujeres. Las variables "lugar donde vive" y "con quién vive", fueron significativamente relacionadas con el consumo de anfetaminas y marihuana. Conclusión: El consumo de tabaco, alcohol y marihuana fue el principal identificado en esa población.

Descriptores: Estudiantes; Universidades; Consumidores de drogas; Drogas ilícitas; Edad de inicio

\footnotetext{
* Publication derived from the research project titled: "Magnitude of licit and illicit drug use by freshman students of the Southern University of Chile (Universidad Austral de Chile)". Thisproject was approved by the Research and Development Administration of the Southern University of Chile (Universidad Austral de Chile), Valdivia, Chile. ${ }^{1}$ Registered Nurse, Doctor of Nursing Science, Master of Public Health in Occupational Health. Professor, Institute of Nursing (Instituto de Enfermeria), Department of Medicine, Southern University of Chile (Universidad Austral de Chile).

${ }^{2}$ Registered Nurse, Master of Public Health in Epidemiology, Professor, Institute of Nursing (Instituto de Enfermeria), Department of Medicine, Southern University of Chile (Universidad Austral de Chile).

${ }^{3}$ Nurse, Adjunct Professor, Institute of Nursing (Instituto de Enfermeria), Department of Medicine, Southern University of Chile (Universidad Austral de Chile).
} 


\section{INTRODUCTION}

According to the Global Status Report on Alcoholand Health published by the World Health Organization,during the year 2004, two billion people drank alcohol, and 76.3 million reported problems associated with alcohol abuse. The consequences of alcohol abuse include 60 different diseases and associated direct and indirect economic costs totaling $\$ 1071$ billon US dollars ${ }^{(1)}$. Tobacco consumption in 2010 was estimated at 7.1 million tons worldwide, and it was projected that 1.6 billion people will consume tobacco by $2025^{(2)}$. Tobacco causes more than 5 million deaths a year, and in the $21^{\text {st }}$ century, it is predicted that tobacco could kill approximately one billion people ${ }^{(3,4)}$.

The World Drug Report(2010) from the United Nations Office on Drugs and Crime reported that 155 250 million people worldwide consumed drugs in 2008. The most commonly abused substance was marijuana, followed by amphetamines, cocaine, and opiates ${ }^{(5)}$.

Latin American university students exhibited the highest ratesof legal and illegal drug use compared with the general population. Drug consumption rates exceeded $60 \%$ for alcohol, $30 \%$ for tobacco, and 3\% for marijuana. Significant differences were found for gender ${ }^{(6-9)}$ and age at initiation of drug use $(\mathrm{p}<0.000)^{(10)}$.

In 2010, the report of the Brazilian national survey on alcohol, tobacco, and other drugs reported that the licit and illicit drugs most frequently used by college students (during their lifetimes) werealcohol, marijuana, inhalants, amphetamines, and tranquilizers. Furthermore, over the last 12 months, alcohol, tobacco, marijuana, amphetamines, and tranquilizers werethe drugs most frequently consumed by college students ${ }^{(11)}$. Percentage differences between men and women were found. The illicit drugs most heavily consumed by men weremarijuana, amphetamines, inhalants, tranquilizers, and hallucinogens. In contrast, women predominantly consumed amphetamines, tranquilizers, marijuana, analgesics, opiates, and inhalants-hallucinogens ${ }^{(11)}$.

Nevertheless, college students preferred to consume legal drugs such as alcohol and tobacco. This pattern of drug useconstitutesbehaviors endemic to this population ${ }^{(9-13)}$.

The ChileanNational Council for the Control of Narcotics demonstrated that cigaretteconsumption among Chilean youth remained stable over a 5 -year period (2004 - 2008).Alcohol consumption in "the previous month" decreased by $3-5$ percentage points. Marijuana use rose considerably among adolescents $12-18$ years of age $(6.2 \%$ in 2004 to $9.1 \%$ in 2008), and cocaine use rose steadily starting from the year 2004, reaching $1.8 \%{ }^{(8)}$. Among college students (2002), the drug consumption rates (for the previous year) were
$15.8 \%$ for marijuana, $4.2 \%$ for cocaine, and $0.9 \%$ for paste-based drugs. Regarding marijuana, the consumption rate in men was twice that of women, while the difference was narrower for cocaine use. Paste-based drugs were exclusively consumed by men ${ }^{(14)}$.

The highest consumption rates for marijuana were clustered around students ranging from $17-25$ years of age $(16.7 \%)$, with rates declining after 26 years of age $(10 \%)$. The average age ofalcohol consumption onset was approximately 12 years (range, $5-19$ years). Many individuals started consuming alcohol before 14 years of age, with a significant difference between genders ${ }^{(15-17)}$. This result is important because the early use of substances such as tobacco and alcohol results in a higher possibility of suffering long-term effects of substance abuse along with the risk of abusing other, more harmful drugs ${ }^{(18)}$.

Groups at high risk for licit and illicit substance abuse are those who have friends with patterns of drug use (19). This situation is one of the best predictors of tobacco and alcohol use. Family structure and family dynamics are among the protective factors against drug use ${ }^{(20)}$.

Motives for initiating use are related to curiosity, feeling of wellness, acceptance, friendship, fear, frustration, a way of dealing with personal problems, and learning from already established role models ${ }^{(19)}$. Factors characteristic of adolescents and young adults such as egocentrism, searching for short-term recognition and gratification, rebelliousness, and struggle against the establishment can also be factors involved in triggeringdrug use(21). We confirm that this age range is a period of decision-making that depends on the ability of individuals to address moral dilemmas and to anticipate consequences ${ }^{(19)}$.

\section{METHODS}

The general study objective was aimed at characterizing drug use and demographic factors in the population of freshman students enrolled at The Southern University of Chile (Universidad Austral de Chile).

This cross-sectional, observational study of the association between demographic variables and drug use was conducted during the second semester of 2008 at the Southern University of Chile (Universidad Austral de Chile) with campuses located on the Isla Teja and Puerto Montt. This institution offers a total of $32 \mathrm{ma}-$ jors, with the Puerto Montt campus being equivalent in size to an academic department. The random sample was proportionally stratified by department and major, with a total sample of 1172 students $(51.2 \%)$,and the statistical error was set at 0.02 to obtain greater precision in the results. The sample was obtained from a total of 2287 freshman students admitted to the university. Within the age distribution, there was a group of 
students age 30 and older corresponding to $0.24 \%$ (2 people), which was included in the sample and did not affectthe statistical validity of the results.

The self-administered survey comprised 2 parts. The first part corresponded to a general data section, namely, the experimental version of the assessment tool for Detection of Alcohol and Drug Problems in Adolescents (DEP-ADO) developed by M. Germaín (2005) and adapted by the Psychology Department of the La Frontera University (Universidad de la Frontera), Chile 2005. The second part included a test for alcohol dependence, namely, the Alcohol Use Disorders Identification Test (AUDIT). The entire survey was evaluated by psychologists from the research team and piloted by nursing students who offered pertinent suggestions. The survey was administered by properly trained senior nursing students. The nursing studentsrandomly distributed the survey in each classroom according to the curriculum of each department. The survey participants had 30 minutes to answer the questionnaire, with the class teacher absent during that time. The data were collected from June to December of 2008. A sample of 845 students based on voluntary participation was obtained after the survey was completed(for a response rate of $72 \%$, equivalent to $37 \%$ of the total population).

The data were processed and analyzed with the statistical software package SPSS 15.0 for Windows. Fisher's exact test was used to establish significance for categorical variables. An ANOVA procedure was applied for constant and categorical variables with more than 2 categories. A logarithm was applied to constant variables that did not have a normal distribution. In addition, the Mann-Whitney $\mathrm{U}$ test was applied for cases in which the condition of non-normality was persistent and associated with categorical variables from 2 groups. For all tests, a p-value $<0.05$ was considered significant.

This study(project code S-2008-38) and the voluntary informed consent form were approved by the Research Administration and the Ethics Committee of the Department of Medicine of the Southern University of Chile (Universidad Austral de Chile). Each survey contained a section where students provided their national identification (ID) number (RolÚnicoTributario). With this ID number, it was possible to determine whether students had a previous history of drug use and to refer students to a rehabilitation center in the future. During the administration of the survey questionnaire, the students received contact information for rehabilitation centersto allow the students to request additional information, if so desired.

\section{RESULTS}

The average age of the student population was 19.1 years (standard deviation, $\mathrm{SD}, \pm 1.39$; confidence interval, CI, 19.02 - 19.21) with a mode value of 19 years of age, a minimum age of 17 years, and a maximum age of 28 years. Students were predominantly male $(52 \%)$ and single (male and female, $98.5 \%)$. The department with the highest proportion of students was Engineering Sciences (19.8\%), followed by the Puerto Montt campus (18.3\%) and the Department of Medicine (14.4\%). A large number of students lived with their parents $(34.8 \%)$. The other students lived with other young acquaintances (17.3\%), with other family members $(14.8 \%)$, and with friends $(12.8 \%)$. Regarding the physical place of residence, the students lived mainly in their parents' house $(38 \%)$, followed by boarding houses $(18.3 \%)$, living independently at their family's cabin (16.2\%), and student housing (10.4\%).

Regarding licit and illicit drug use, alcohol consumption showed the greatest proportion of users, with $77.6 \%$ of the total population partaking. Occasional drinking was the most common behavior (30.4\%), followed by "drinking on weekends" and "one or two times a week" (27.9\%). Daily consumption reached $0.6 \%$. Regarding tobacco, $47.7 \%$ reported consuming tobacco; $14.7 \%$ consumed tobacco once a month, $14.3 \%$ used it occasionally, and $3.7 \%$ consumed it daily. Regarding marijuana, $26.5 \%$ said they had used it; occasional use reached $17.9 \%$, followed by "once a month" at $3.9 \%$ and daily marijuana use at $0.5 \%$. A total of $3.7 \%$ of the population reported having used other substances on a daily basis (such as anticonvulsants, antidepressants, hypnotics, tranquilizers). Hallucinogens were used by $2.4 \%$ of the sample, with occasional use at $2.2 \%$ and "three or more times a week, but not every day" at $0.2 \%$. The use of the remaining substances wasdistributed between $0.4 \%$ and $1.8 \%$ (Table 1 ).

Table 1. The numerical and percentage distributions of the study population according to licit and illicit drug use in the previous 6 months- 06 to $12 / 2008$

\begin{tabular}{lccc}
\hline Substance & Do not use & Use & Total \\
\cline { 2 - 4 } & $\mathbf{n}^{\mathbf{0}} \mathbf{( \% )}$ & $\mathbf{n}^{\mathbf{0}} \mathbf{( \% )}$ & $\mathbf{n}^{\mathbf{0}} \mathbf{( \% )}$ \\
\hline Tobacco & $437(52,3)$ & $398(47,7)$ & $835(100)$ \\
Alcohol & $188(22,4)$ & $650(77,6)$ & $838(100)$ \\
Marijuana & $609(73,5)$ & $220(26,5)$ & $829(100)$ \\
Cocaine & $812(98,2)$ & $15(1,8)$ & $827(100)$ \\
Paste-based & $820(99)$ & $8(1)$ & $828(100)$ \\
Glue & $822(99,4)$ & $5(0,6)$ & $827(100)$ \\
Hallucinogens & $809(97,6)$ & $20(2,4)$ & $829(100)$ \\
Heroin & $799(99,6)$ & $3(0,4)$ & $802(100)$ \\
Amphetamines & $808(98,3)$ & $14(1,7)$ & $822(100)$ \\
Other substances & $696(96,3)$ & $27(3,7)$ & $723(100)$ \\
\hline
\end{tabular}


Regarding the relationship between different drug use and gender, significance was found only with alcohol $(p=$
$0.000)$ and marijuana $(\mathrm{p}=0.000)$, confirming that the use of these substances was higher in men than in women (Table 2).

Table 2. The distribution of first-year freshman students of a Chilean university according to gender and use of licit and illicit substances in the previous 6 months- 06 to $12 / 2008$

\begin{tabular}{|c|c|c|c|c|c|c|}
\hline \multirow{3}{*}{ Substance } & \multicolumn{2}{|c|}{ Male } & \multicolumn{2}{|c|}{ Female } & \multirow{2}{*}{\multicolumn{2}{|c|}{ Significance }} \\
\hline & Do not use & Use & Do not use & Use & & \\
\hline & $\mathrm{n}^{\mathrm{o}}(\%)$ & $\mathrm{n}^{\circ}(\%)$ & $\mathrm{n}^{\circ}(\%)$ & $n^{\circ}(\%)$ & $\mathbf{X}^{2}$ & Fisher $\mathbf{P}$ \\
\hline Tobacco & $205(52.7)$ & $184(47.3)$ & $201(55.7)$ & $160(44.3)$ & 0.669 & 0.22820 \\
\hline Alcohol & $66(17)$ & $323(83)$ & $103(28.4)$ & $260(71.6)$ & 14.02 & 0.00012 \\
\hline Marijuana & $263(68.1)$ & $123(31.9)$ & $288(80.7)$ & $69(19.3)$ & 15.21 & 0.00000 \\
\hline Cocaine & $380(98.4)$ & $6(1.6)$ & 351 (98.6) & $5(1.4)$ & 0.028 & 0.55494 \\
\hline Paste-based & $382(99)$ & $4(1)$ & 355 (99.4) & $2(0.6)$ & 0.525 & 0.38048 \\
\hline Glue & $386(99.7)$ & $1(0.3)$ & 355 (99.7) & $1(0.3)$ & 0.003 & 0.72903 \\
\hline Hallucinogens & $377(97.4)$ & $10(2.6)$ & $350(98.0)$ & $7(2.0)$ & 0.323 & 0.37509 \\
\hline Heroin & 378 (99.7) & $1(0.3)$ & $340(100)$ & $0(0)$ & 0.898 & 0.52712 \\
\hline Amphetamines & $380(98.2)$ & $7(1.8)$ & 347 (98.6) & $5(1.4)$ & 0.174 & 0.45212 \\
\hline Other substances & $332(96)$ & $14(4)$ & $294(96.7)$ & $10(3.3)$ & 0.261 & 0.38313 \\
\hline
\end{tabular}

$\mathrm{gl}=1$

Marijuana use was greater in the Department of Engineering Sciences (17.7\%), and the use of cocaine, hallucinogens, and amphetamines was higher in the Department of Philosophy-Humanities and the Academic Vice-Rectory (Table 3).

Table 3. The distribution of first-year freshman students of a Chilean university according to department of study- 06 to $12 / 2008$

\begin{tabular}{|c|c|c|c|c|c|c|c|}
\hline \multirow{3}{*}{ Department } & \multicolumn{7}{|c|}{ Substance Use } \\
\hline & Alcohol & Mariju. & Cocaíne & Others & Aluc. & Anphet. & Tobacco \\
\hline & $n^{\circ}(\%)$ & $\mathrm{n}^{\circ}(\%)$ & $\mathrm{n}^{\circ}(\%)$ & $\mathrm{n}^{0}(\%)$ & $\mathrm{n}^{\circ}(\%)$ & $\mathrm{n}^{\circ}(\%)$ & $\mathrm{n}^{\mathrm{o}}(\%)$ \\
\hline Sciences & $41(6.3)$ & $18(8.1)$ & $1(6.7)$ & $2(4.7)$ & $1(5.0)$ & $1(7.1)$ & $27(6.8)$ \\
\hline AgrarianSciences & $9(1.4)$ & $3(1.4)$ & $*$ & $*$ & $*$ & $*$ & $5(1.3)$ \\
\hline EconomicSciences & $61(9.4)$ & $17(7.7)$ & $1(6.7)$ & $3(7.0)$ & $*$ & $1(7.1)$ & $43(10.8)$ \\
\hline ForestrySciences & $29(4.5)$ & $19(8.6)$ & $1(6.7)$ & $3(7.0)$ & $2(10.0)$ & $*$ & $20(5.0)$ \\
\hline Judicial Sciences & $35(5.4)$ & $10(4.5)$ & $*$ & $3(7.0)$ & $*$ & $1(7.1)$ & $25(6.3)$ \\
\hline VeterinarySciences & $42(6.5)$ & $16(7.3)$ & $*$ & $2(4.7)$ & $2(10.0)$ & $*$ & $18(4.5)$ \\
\hline EngineeringSciences & $121(18.6)$ & $44(20)$ & $2(13.3)$ & $3(7.0)$ & $3(15.0)$ & $2(14.3)$ & $76(19.1)$ \\
\hline $\begin{array}{l}\text { Philosophy and } \\
\text { Humanities }\end{array}$ & $76(11.7)$ & $39(17.7)$ & $6(40.0)$ & $11(25.6)$ & $8(40.0)$ & $5(35.7)$ & $53(13.3)$ \\
\hline Medicine & $99(15.2)$ & $9(4.1)$ & $1(6.7)$ & $7(16.3)$ & $1(5.0)$ & $1(7.1)$ & $40(10.1)$ \\
\hline Puerto Montt Campus & $119(18.3)$ & $38(17.3)$ & $1(6.7)$ & 5 (11.6) & $1(5.0)$ & $1(7.1)$ & $77(19.3)$ \\
\hline Academic Vice-Rectory & $18(2.8)$ & $7(3.2)$ & $2(13.3)$ & $4(9.3)$ & $2(10.0)$ & $2(14.3)$ & $14(3.5)$ \\
\hline Total & $651(100)$ & $221(100)$ & $15(100)$ & $43(100)$ & $20(100)$ & $14(100)$ & $398(100)$ \\
\hline
\end{tabular}

*Value $=0$ 
The average age at initiation of alcohol consumption was 16.0 years ( $\mathrm{SD} \pm 1.8$; CI, $15.75-16.15)$. The average age at initiation of drug use was 16.42 years $(\mathrm{SD} \pm 2.76$; CI, 15.91 - 16.94). The hypothesis "initiation of alcohol and drug use is associated with gender and occurs early in men" was rejected in this study because significance was not reached (alcohol: $\mathrm{U}=8.629, \mathrm{p}=0.514$ )

Regarding the number of times that a person consumed 8 alcoholic beverages in the previous 12 months, the mean value corresponded to "12.15 times" (SD \pm 18.6) among men and "8.55 times" among women (SD \pm 9.5$)$; this difference was not significant $(t=0.966, \mathrm{p}=0.335)$. The hypothesis "the distribution of these variables is significantly different between departments" was supported because in this study; the results of the ANOVA wereF= $6.43(\mathrm{p}<$ $0.000)$ for men and $\mathrm{F}=8.422(\mathrm{p}<0.000)$ for women. The Department of Forestry Sciences had the lowest consumption rate compared with other departments $(p<0.05)$. "Living in their parents' house" was significantly related only to the use of amphetamines ( $p=0.040$; Table 4).

Table 4. The distribution of first-year freshman students of a Chilean university according to place of residence and type of substance used - 06 to $12 / 2008$.

\begin{tabular}{|c|c|c|c|c|c|c|}
\hline \multirow{3}{*}{ Substance } & \multicolumn{2}{|c|}{ Live in parents' house } & \multicolumn{2}{|c|}{ Others } & \multirow{2}{*}{\multicolumn{2}{|c|}{ Significance }} \\
\hline & \multirow{2}{*}{$\begin{array}{c}\text { Do not use } \\
n^{\circ}(\%)\end{array}$} & \multirow{2}{*}{$\begin{array}{c}\text { Use } \\
n^{\circ}(\%)\end{array}$} & \multirow{2}{*}{$\begin{array}{c}\text { Do not use } \\
n^{\circ}(\%)\end{array}$} & \multirow{2}{*}{$\begin{array}{c}\text { Use } \\
n^{\circ}(\%)\end{array}$} & & \\
\hline & & & & & $\mathrm{x} 2$ & Fisher $\mathbf{P}$ \\
\hline Tabaco & $167(52.68)$ & $150(47.32)$ & $270(52.12)$ & $248(47.87)$ & 0.025 & 0.466 \\
\hline Alcohol & $73(23.25)$ & $241(76.75)$ & $115(21.94)$ & $409(78.05)$ & 0.191 & 0.361 \\
\hline Marihuana & $237(75.24)$ & $78(24.76)$ & $372(72.37)$ & $142(27.63)$ & 0.822 & 0.205 \\
\hline Cocaína & $307(98.40)$ & $5(1.60)$ & $505(98.05)$ & $10(1.94)$ & 0.126 & 0.475 \\
\hline Pasta Base & 311 (99.36) & $2(0.64)$ & $509(98.83)$ & $6(1.16)$ & 0.563 & 0.362 \\
\hline Pegamento & $310(99.36)$ & $2(0.64)$ & $512(99.42)$ & $3(0.58)$ & 0.011 & 0.623 \\
\hline Alucinógenos & $308(98.09)$ & $6(1.91)$ & $501(97.28)$ & $14(2.72)$ & 0.540 & 0.313 \\
\hline Heroína & $304(99.67)$ & $1(0.33)$ & $495(99.60)$ & $2(0.40)$ & 0.028 & 0.676 \\
\hline Anfetaminas & $303(97.12)$ & $9(2.88)$ & $505(99.02)$ & $5(0.98)$ & 4.193 & 0.040 \\
\hline Otras sustancias & $258(95.56)$ & $12(4.44)$ & $438(96.69)$ & $15(3.31)$ & 0.604 & 0.280 \\
\hline
\end{tabular}

$\mathrm{gl}=1$

Regarding the use of legal drugs and the relationship to the student's place of residence, although it was not significant, tobacco showed the highest proportion of use in those who lived in a studio (51.6\%), cabin $(55.6 \%)$, or student housing $(54.1 \%)$ compared with those who livedin their parents' house (47.3\%).Regarding alcohol, those who lived in a cabin $(83.9 \%)$ or student housing $(82.6 \%)$ showed higher consumption rates compared with those who lived in their parents' house $(76.8 \%)$. Regarding the most common illicit drug, marijuana, the distribution was concentrated in those students that were living in a cabin $(36.8 \%)$, student housing $(32.9 \%)$, or a studio $(26.2 \%)$. Living with parents or relatives, friends, acquaintances, or strangers, independent of the place, was associated only with marijuana use $(\mathrm{p}=0.009$; Table 5).

Table 5. The distribution of first-year freshman students of a Chilean university according to roommate and type of substances consumed- 06 to $12 / 2008$

\begin{tabular}{|c|c|c|c|c|c|c|}
\hline \multirow{3}{*}{ Substance } & \multicolumn{2}{|c|}{ Bothparents } & \multicolumn{2}{|c|}{ Others } & \multirow{2}{*}{\multicolumn{2}{|c|}{ Significance }} \\
\hline & Do not use & Use & Do not use & Use & & \\
\hline & $n^{\circ}(\%)$ & $\mathrm{n}^{\circ}(\%)$ & $\mathrm{n}^{\circ}(\%)$ & $\mathrm{n}^{\circ}(\%)$ & $\mathbf{X}^{2}$ & Fisher $\mathbf{P}$ \\
\hline Tobacco & $149(52.84)$ & $133(47.16)$ & $288(52.07)$ & $265(47.92)$ & 0.043 & 0.447 \\
\hline Alcohol & $71(25.45)$ & $208(74.55)$ & $117(20.93)$ & $442(79.06)$ & 2.183 & 0.083 \\
\hline Marijuana & $221(78.65)$ & $60(21.35)$ & $388(70.80)$ & $160(29.20)$ & 5.864 & 0.009 \\
\hline Cocaine & 275 (99.28) & $2(0.72)$ & $537(97.64)$ & $13(2.36)$ & 2.788 & 0.076 \\
\hline Paste-based & 278 (99.64) & $1(0.36)$ & $542(98.73)$ & $7(1.27)$ & 1.624 & 0.188 \\
\hline Glue & $276(99.64)$ & $1(0.36)$ & $546(99.27)$ & $4(0.73)$ & 0.411 & 0.457 \\
\hline Hallucinogens & 274 (98.21) & $5(1.79)$ & $535(97.27)$ & $15(2.73)$ & 0.688 & 0.284 \\
\hline Heroin & $270(99.63)$ & $1(0.37)$ & $529(99.62)$ & $2(0.38)$ & 0.000 & 0.735 \\
\hline Amphetamines & 272 (98.19) & $5(1.81)$ & $536(98.35)$ & $9(1.65)$ & 0.026 & 0.537 \\
\hline Othersubstances & $230(96.64)$ & $8(3.36)$ & $466(96.08)$ & $19(3.92)$ & 0.137 & 0.445 \\
\hline
\end{tabular}

$\mathrm{gl}=1$ 


\section{DISCUSSION}

Consumption of licit and illicit drugs is a problem for society, particularly for colleges, as demonstrated by the high proportion of alcohol, tobacco, and marijuana use among students. Legal drugs were the primary choice of students, as confirmed by students' tendencies to use alcohol and tobacco ${ }^{(20,22-23)}$. In terms of illicit drugs, the most commonly consumed was marijuana, followed by cocaine at $0.7 \%$ and ecstasy $(1.8 \%)^{(20,22)}$. This behavior is similar to that found at the Southern University (Universidad Austral); however, other substances occupied third place.

In general, drug use is distributed differently in men and women, with males consuming alcohol at a higher rate ${ }^{(24)}$. Nevertheless, women did show a preference for drugs such as benzodiazepines, stimulants, and appetite stimulants ${ }^{(25-27)}$, which to some extent can be involved in various pathologies or in suicide attempts ${ }^{(28)}$. A greater consumption of alcohol and marijuana by men compared with women is recognized. Even though the tendency is consistent for other drugs, there was no significant association. It should be noted that as society develops, the gap between sexes in drug use narrows, as the use of some drugs by women is equal to or greater than the use by men ${ }^{(29)}$.

The distributions of use between departments exhibited significant differences with respect to certain drugs. This observation was an important result because maps of risk can be established within a university, whichcould allow resourcesto be focused and increase the effectiveness of measures aimed at confronting student drug use.In terms of constant use over the previous year, especially alcohol byboth men and women, a marked tendency was observed in the distribution by department. This finding demonstrates the need to analyze consumption practices in eachdepartment because, in many instances, use is clearly related to the student's major. In addition, if evidence indicates that alcohol consumption is greater in men, interventions can be focused on this segment ${ }^{(21)}$.

Initiation of alcohol use occurs at an early age in both women and men. In this study, there were no significant differences regarding age, even though the minimum age at initiation is less for women regarding alcohol consumption and for men regarding drug use. Nevertheless, studies have reported that men start using drugs earlier than women ${ }^{(17-18)}$. Early use has been associated with problematic drug abuse in adulthood. This situationexplains tobacco, alcohol, and marijuana use patterns. Wheninitiation occurs at an early age, drug use intensifies as the individual develops; therefore, the need and willingness to quit the habit decrease, and the problematic consumption leads the person to use other, more harmful drugs ${ }^{(17)}$.

The environment in which college life develops is important because if individuals entering college are already drug users, their problem is accentuated. The students are away from family, and their peers could also be users. This issue represents a complex problem that needs to be addressed through diverse strategies. Among the probable factors for the initiation or increase in legal drug use are the following: having friends and family who drink alcohol until inebriated ${ }^{(30)}$; communication media; personal characteristics; need for belonging; curiosity; pleasure; and idleness ${ }^{(7)}$.

In this study, the habits and influence of persons living with students are associated with the use of marijuana, with greater consumption occurring in those who did not live with both parents. The student's place of residence is associated with amphetamine use. Being away from family affects a significant proportion of students (living with other young acquaintances, strangers, or living in a room, cabin, or student housing). However, the relationship of this factor with drug use is not clear. The former is different from other studies ${ }^{(31)}$ that indicate that the use of cannabis is mainly associated with critical family relationships and not with being away from family.

\section{CONCLUSIONS}

Drug use is widespread in college life, forming part of personal emotional development in confronting problems faced by individuals, particularly if this habit was formed at an earlier age. Drug abuse could be accentuated, leading to poor performance, repetition of course work, and even a loss of enrollment. Drug use presents a health and economic risk to students, who thus face an uncertain and grim future.

The problem is not the harder drugs, which are used at a lower rate but must be detected and treated, but the licit drugs such as tobacco and alcohol and the illicit drug marijuana. These substances are more frequently used but are perceived by youth as innocuous.

This study supports the hypothesis thatsignificant gender-based differences exist in drug use for alcohol and marijuana. However, these differences are absentfor other drug consumption, with drug use being greater inthe male population.Even though proportionately, men lead the way, the hypothesis that men drink more than women is rejected. It is not clear whether living away from parents is an important factor in the use of licit or illicit drugs. Thus, it is recognized that there was not a deeper analysis of the types of relationships that the university students had with their families. 


\section{REFERENCES}

1. World Health Organization. Department of Mental Health and Substance Abuse. Global status report on alcohol 2004. Geneva: WHO; 2004.

2. Food and Agriculture Organization of the United Nations. Projections of tobacco production, consumption and trade to the year 2010. Rome: Food and Agriculture Organization of the United Nations; 2003.

3. Organización Mundial de la Salud. Informe OMS sobre la epidemia mundial de tabaquismo, 2008. Plan de medidas MPOWER. Ginebra, Suiza; 2008. Report No.: WM 290

4. Pillon SC, Jora NP, Amorim GP, Domingos JB, Santos RA. Smoking among users of a psychosocial care center for alcohol and drugs: a pilot study. Acta Paul Enferm. 2011; 24(3):313-9.

5. Naciones Unidas. Oficina contra La Droga y El Delito. Informe mundial sobre lãs drogas 2012. Resumen ejecutivo [Internet] [citado 2012 Set 10]. Disponível em: http:// www.unodc.org/documents/data-andanalysis/WDR2012/ Executive_summary_spanish.pdf

6. Piedra Chavez KA, O’Brien B, Pillon SC. Drugs use and risk behavior in a university community. Rev Latinoam Enferm. 2005;13 Spec No:1194-200.

7. Hernández Rodríguez VM, Scherer ZA. Undergraduate students' motivations for the consumption of legal drugs. Rev Latinoam Enferm. 2008;16 Spec No:572-6.

8. Rodríguez J, Hernández E, Fernández AM. [A gender comparison of legal and illicit drug consumption]. Rev Méd Chil. 2007;135(4):449-56. Spanish

9. Lucas AC, Parente RC, Picanço NS, Conceição DA, Costa KR, Magalhães IR, et al. Use of psychoactive drugs by health sciences undergraduate students at the Federal University in Amazonas, Brazil. Cad Saúde Pública. 2006; 22(3):663-71.

10. Consejo Nacional para el Control de Estupefacientes. Octavo estudio nacional de drogas en población general de Chile, 2008: principales resultados. Santiago: Ministerio del Interior; 2009.

11. Secretaria Nacional de Políticas sobre Drogas I Levantamento nacional sobre o uso de álcool, tabaco e outras drogas entre universitários das 27 capitais brasileiras. Brasília: SENAD; 2010

12. Tockus D, Gonçalves PS. [Detection of drugs abuse among Medicine students in a private university]. J Bras Psiquiatr. 2008;57(3):184-7. Portuguese

13. Portugal FB, SouzaRS, Buaiz V, Siqueira MM. [Use of drugs by Pharmacy students at the Federal University in Espírito Santo]. J Bras Psiquiatr. 2008; 57(2):127-32. Portuguese

14. Consejo Nacional para el Control de Estupefacientes. Estudio nacional de drogas en la población general de Chile, 2000. Santiago: CONAGE; 2003.

15. Vieira DL, Ribeiro M, Laranjeira R. Evidence of association between early alcohol use and risk of later problems. Rev Bras Psiquiatr. 2007;29(3):222-7.

16. Iglesias V, Cavada G, Silva C, Cáceres D. [Early tobacco and alcohol consumption as modifying risk factors on marijuana use]. Rev Saúde Pública. 2007;41(4):517-22. Spanish

17. Hernández López T, Roldán Fernández J, Jiménez Frutos
A, Mora Rodríguez C, Sánchez-Garnica DE, Pérez Álvarez MT. The starting age of drugs consumption as an indicator for problematic consumption. Interv Psicosoc.2009;18(3):199-212.

18. Herrera-Vázquez M, Wagner FA, Velasco-Mondragón E, Borges G, Lazcano-Ponce E. [Onset of alcohol and tobacco use and transition to other drug use among students from Morelos, Mexico. Salud Publica Méx. 2004;46(2):132-40.

19. Martínez Rodriguez G, LuisMA. Descriptive study of drugs use among adolescents in higher middle education in Monterrey, Nueva León, Mexico. Rev Latinoam Enferm. 2004;12(No Espec):391-7.

20. Cáceres D, Salazar I, Varela M, Tobar J. [Drug use in college students and its relation to psychological factors of risk and protection]. Univ Psychol. 2006;5(3):521-34. Spanish

21. Acero IC. Consumo de alcohol en universitarios: relación funcional con los factores sociodemográficos, las expectativas y la ansiedad social. Acta Colomb Psicol. 2005; 8(1):91-120.

22. Bustamante IV, Strike C, Brands B, Cunningham J, Wright MG. [Perceived norms among peruvian students for drug use among peers]. Rev Latinoam Enferm.2010;17(No Espec.):858-64. Spanish

23. Soares MH, Luís MA, Corradi-Webster CM, Martins JT, Hirata AG. Psychological concept of optimism and drug use among nursing students. Acta Paul Enferm. 2011; 24(3):393-9.

24. Bastos FI, Bertoni N, Hacker MA; Grupo de Estudos em População, Sexualidade e Aids. Drug and alcohol use: main findings of a national survey, Brazil 2005. Rev Saúde Pública. 2010;42 Suppl 1:109-17.

25. Díaz JB, Brands B, Adlaf E, Giesbrecht N, Simich L, Wright MG. Drug consumption and treatment from a family and friends perspectives: Guatemala]. Rev Latinoam Enferm. 2010;17(No Espec):824-30. Portuguese

26. Oliveira JF, Paiva MS, Valente CM. The interference of the care context with the visibility of the drug consumption by women. Rev Latinoam Enferm. 2007;15(2):247-52.

27. Pach J, Tobiasz-Adamczyk B, Jablonski P, Brzyski P, Krawczyk E, Satora L, et al. Drug free universities--trends in illicit drugs use among Kraków university students. Przegl Lek. 2005;62(6):342-50.

28. Schwarz UI, Ruder S, Krappweis J, Israel M, Kirch W. [Epidemiology of attempted suicide using drugs. An inquiry from the Dresden University Clinic. Dtsch Med Wochenschr. 2004;129(31-32):1669-73. German

29. Boland M, Fitzpatrick P, Scallan E, Daly L, Herity B, Horgan $\mathrm{J}$, et al. Trends in medical student use of tobacco, alcohol and drugs in an Irish university, 1973-2002. Drug Alcohol Depend. 2006;85(2):123-8.

30. Urrego Mendonza DZ. Consumo de sustancias psicoactivas en estudiantes de especialidades médicas, Bogotá 2001. Rev Salud Pública. 2002;4(1):59-73.

31. Guxens M, Nebot M, Ariza C, Ochoa D. Factors associated with the onset of cannabis use: a systematic review of cohort studies. Gac Sanit. 2007;21(3):252-60. 